\title{
Understanding Theme and Rheme of Babu Solong (A Traditional Folktale from Mamasa, West Sulawesi)
}

\author{
Ismail $^{1 *}$ and Nina Kardina ${ }^{2}$ \\ ${ }^{1,2}$ Post Graduate program of English Language Education, Universitas Muhammadiyah Parepare, Indonesia \\ *Fazfath@gmail.com
}

\begin{abstract}
Language was not fully transferred directly. Sometimes people used media to deliver their messages. One of the media that was widely used was stories. Traditional stories used theme and rheme in delivering the message and with their unique ways prompt a language that occasionally turns into values that can change children's behavior. And it is assumed that stories are still an effective media both in teaching or in administering good values in our community folktale is one of cultural heritage that should be preserved. It has been told passed down verbally from generation to generation. This study focused on the aspect of discourse used in a traditional folktale. The aspects that will be given underlined are theme and rheme. By analyzing the transcript of Babu Solong story a traditional folktale from Mamasa, West Sulawesi, there is some evidence that will give new information. The research used a qualitative descriptive study. The result of the study shows that this folktale used four kinds of theme and rheme patterns. They are: zig-zag pattern, reiteration pattern, combine theme pattern, and hierarchical pattern. From the four patterns, the story mostly used hierarchical patterns. It is because each theme and rheme introduce several different pieces of information, then each is taken and the next clause is made. Another result from this study is the cultural aspects that immerse in the story. From this cultural aspect, readers will find some evidence that proved the folktale will absorb the culture of how the story told by the storyteller.
\end{abstract}

Key words: Babu Solong, cultural aspect, folktale, rheme, theme.

\section{Introduction}

A language is a universal tool that is used as a sender of the message to anyone as the target information. It is the bridge that we hold to transfer messages like ideas, thoughts, needs, purpose, and others. There are several functions of language [1], they are referential, poetic, emotive, conative, and metalinguistic functions. This function is used to convey the purpose of the message sender to others in accordance that people understood what he/she means. The language was not fully transferred directly. Sometimes people used media to deliver their message. One of the media that is widely used is stories. Stories had been used to deliver an important message to others especially for children. And it has been proved that it is one of the effective ways. Although it is one of the effective methods the usage of stories is slowly left behind. It is vastly replaced by instant entertainment like TikTok, Instagram, webtoon, etc. 
It is not a thought that used to neglect the presence of those powerful information tools. But it is already believed that our ancestor had proved their method in creating a strong and characterized generation through stories. Traditional stories used themes and rhemes in delivering the message and with their unique ways prompt a language that occasionally turns into values that change children's behavior. And it is assumed that stories are still an effective media both in teaching and in administering good values in our community.

The theme is "a formal grammatical category which refers to the initial element in a clause" [2], "the idea represented by the constituent at the starting point of the clause" [3], a starting point or signpost for the message chosen by the speaker [4], "the first constituent of the clause" [5], and generally known as what the message is concerned with, the point of departure for what the speaker is going to say [6]. The term Rheme, on the other hand, is defined as "everything that follows the Theme" [7], "part of the clause in which Theme is developed [8], "all the rest of the clause" [9], and "the remainder of the message, the part in which the Theme is developed" [10].

The word folklore comes from Italian folklore which literally means a small new thing, and is then interpreted as short stories in prose. In Latin, the word folklore comes from folklore which is also derived from the word novels which means new. Folklore is a work that is realistic and contains psychological value depth so that folklore can develop from historical stories, letters, non-fiction forms, or documents, while romances or romance is more poetic. Most people who read a folk tale just want to enjoy the story presented by the author. Readers will only get a direct impression of general and specific parts of the story that are interesting. But sometimes folklore was told by a storyteller. Written or spoken folklore can give interesting experiences.

Folklore can also be prose that is conveyed orally story. People are better known to the public as fairy tales, legends, or oral stories historical background. This folk tale, alive and growing in society without knowing who the author is. As a genre of Oral literature, folklore has many benefits for society. It contains various norms, morals, education, heroism, struggle, a devotion that can be followed by today's people or become a source of inspiration to do something today. Folklore can be a myth or an incident fiction that never or may not happen, or maybe ever occur but are not intact, or have undergone changes in content or the plot of the story is compared to the facts that have happened. Because spoken orally, the depth of value contained in Folklore can vary depending on the ability of the speaker. Most folk tales have the characteristics of not knowing the year and place of the incident. If there is a place of occurrence, the content of the story is usually about the origin of the name of the place or the tradition that developed or was found in the place incident [11].

In West Sulawesi, there are many cultural diversities that enrich our Culture in Indonesia. In Mamasa a hilly part of west Sulawesi, there was folklore that has been told for ages. This folklore is told from one generation to the next generation. Sometimes when the family enjoys their spare time the elder will tell the story. Or on one occasion, and all the family went home from their wanderer in another place. Then the elder will tell the story. One of the stories that are always told from generation to generation is "Babu Solong".

\section{Babu Solong (Synopsis)}

Once upon a time in the hilly land of Mamasa there lived a family in a small hut. The family consists of a father (ambe), mother (indo'), and a son (Babu Solong). This family makes a living from farming on a patch of rice fields that they own. Behind this simple family life, there is one thing that bothers the father and mother of this boy. This boy has a habit of eating a lot. Every day the mother has to cook twice as much because her son's appetite is higher than his age. Even though both parents really love their son Babu Solong. But they can't help but feel burdened by the habits of their son who eat too much. Over time, because they could no longer meet the food needs of their very large child, Babu's parents searched for ideas. Both Babu Solong's parents agreed to eliminate their child. But without them realizing it while discussing Babu Solong accidentally overheard their conversation.

One day Ambe Babu Solong invited Babu Solong to go find wood in the middle of the forest. They left early in the morning to reach the middle of the forest by midday. Arriving in the middle of the forest they then chose the biggest and tallest tree to be their firewood supply. So the two of them started chopping the big wood. Every time Ambe Babu Solong slashed wood with an ax, Babu Solong digs Paris next to the tree. So until finally, the big tree fell on Babu Solong. Thinking that his son had not been hit by a tree, then Ambe Babu Solong went home. But with his power and big body, Babu Solong with his great strength moved the tree. With a sad feeling, Babu Solong then lifted the big tree up to his house. When he arrives at his house, then he told his parents that he knew they want to eliminate him. But he understands his parent's great difficulties so he decided to leave his parents.

Babu Solong went away to find a new place to live. On his way, he met a trader. He begged the trader so he can come with him. The trader agrees Babu Solong follows him. Then they continue their journey. In the middle of their way, a runaway slave also wants to join them. So they all three continue their journey. While they took a rest, an orphan young boy begged the trader that he let him join them. The trader agreed because they will all need to help the trader in the market. Because they were all hungry, they decided to stay near a pond. It was full of fish. The trader then asked Babu Solong and the two boys caught all the fish for their dinner. After that, they want to cook the fish but unfortunately, they didn't have a pot to steam the fish. Babu Solong offers help that he will go to the nearest village to borrow a clay pot. After walking for a while, he arrived at one village. 
The village was really quiet. But Babu Solong could see all things around him were bigger than their size. Then he entered a place to cook. There he opened the lid of the clay pot and he saw that it was full of the human body. Babu Solong then knew that he had entered a giant village. All the giants eat human beings. Even though Babu Solong was scared but he knew that he had to do something.

He thought of a way to eliminate all the giants. He took his ax and knock at a door. Suddenly the giant's head appear, but before the giant got out of his house, Babu Solong chopped off the giant's head. He kept doing that until all giants were killed. He went back to the trader and told his story. The trader was very grateful because of his braveness. When they went to the giant's village, there they found many gold and treasures. They took all the gold and treasure for them. The trader asked babu Solong to be his servant, but he reject it. He is thankful to the trader and wants to go home. He became a rich man. Babu Solong makes his long journey to come to his village to see his parents. After he arrived, he told the parents his story. His parents were feeling very sorry for their son. They asked forgiveness. Babu Solong and his parents become a wealthy family and live happily ever after.

\section{Methodology}

This study uses a qualitative descriptive method. A qualitative approach relates to the data which is not in the form of numbers, but in words and pictures instead, using statements, sentences, quotations, descriptions, or manuscripts of interviews, photos, and videotapes [12]. The descriptive method demands a researcher to compile the text-reference-based data by encompassing the step-by-step process worked to assemble information [13]. The data was collected by identifying the manuscript of BabuSolong story and exploring some related scientific articles, literature, journal about analysis of a folktale. Data was collected with reading-listening from local villages and story-teller and note-taking techniques. Data analysis techniques through the stages of identification, classification, analysis, and description [14]. The subject of this research was the folktale from Mamasa entitled BabuSolong. The researcher then formulates some research questions as follows:

1. What are the configuration theme and rheme used in the folklore story of Babu Solong?

2. What is the moral value that we learn from the folklore story of Babu Solong?

3. What are the social-cultural aspects in society regarding BabuSolong story?

Based on the problem statement mentioned above, the researcher has the following objective:

1. To identify the theme and rhyme used in the folklore story of Babu Solong

2. To identify the moral value of the folklore story of babu Solong

3. To identify the social-cultural aspect put in Mamasa West Sulawesi society regarding the folklore story of BabuSolong.

\section{Findings and Discussion}

\section{Four Patterns for Theme-Rheme Analysis}

\section{Zig Zag Pattern}

Theme1 Rheme 1

Rheme2 Theme 2

Theme3 Rheme 3

In Pattern (a) the rheme in the previous clause contains an element be the theroe of the next clause

\section{Reilteration Pattern/ Fixed Theme (constant)}

Theme1 Rheme1

Theme1 Rheme2

Theme1 Rheme3

In pattern (b) the theme concerning the previous clause is the same just as the theme concerns the next clause.

\section{Combined Theme Pattern (Multiple)}

Theme1 Rheme1

Theme1 Rheme2

Theme2 Rheme3

Theme3 Rheme4

Theme 4 Rheme 5

Theme5 Rheme6

Theme6 Rheme7 


\section{Hierarchical Patterns}

The fourth pattern is a hierarchical pattern, in this pattern the theme clause introduces a number of different pieces of information, then each is taken and the next clause is made.

The theme is the main purpose of the message in the clause or starting point clause. In other words, Themes are old information usually placed at the front. On the other hand, Rheme is part of the clause after a new theme or information which is usually put behind Theme. Clauses in English in conversation or writing are known that an item has the thematization state placed first First, the clauses that are related to the theme section and are developed in the rheme. Then the thematic structure is the structure that composes the character clause as a message that defines the function of theme and rheme: there is a relationship between the thematic structure in the clause and the construction text, and at the same time a certain pattern emerges [15].

Theme-Rheme Analysis of Babu Solong Folktale

Table 1. Theme-Rheme Analysis of Babu Solong

\begin{tabular}{|c|c|c|c|c|}
\hline Paragraph & Sentences & Theme & Rheme & Analysis \\
\hline 1 & $\begin{array}{l}\text { Once upon a time in the hilly land of } \\
\text { Mamasa there lived a family in a small hut. } \\
\text { The family consists of a father (ambe), } \\
\text { mother (indo'), and a son (Babu Solong). } \\
\text { This family makes a living from farming on } \\
\text { a patch of rice fields that they own. Behind } \\
\text { this simple family life, there is one thing } \\
\text { that bothers the father and mother of this } \\
\text { boy. This boy has a habit of eating a lot. } \\
\text { Every day the mother has to cook twice as } \\
\text { much because her son's appetite is higher } \\
\text { than his age. }\end{array}$ & $\begin{array}{l}\text { Once upon a time in a hilly } \\
\text { land of Mamasa (theme 1) } \\
\text { The family consists of a } \\
\text { father (ambe), mother } \\
\text { (indo'), (rheme 1) } \\
\text { This family makes a living; } \\
\text { Behind this simple family } \\
\text { life; This boy has a habit of } \\
\text { eating a lot. Theme } 3 \\
\text { Every day the mother has } \\
\text { to cook twice as much } \\
\text { theme } 4\end{array}$ & $\begin{array}{l}\text { there lived a family in a } \\
\text { small hut.(rheme 1) } \\
\text { and a son (Babu Solong). } \\
\text { (theme } 2 \text { ); from farming } \\
\text { on a patch of rice fields } \\
\text { that they own. (rheme 2) } \\
\text { there is one thing that } \\
\text { bothers the father and } \\
\text { mother of this boy. rheme } \\
3 \\
\text { because her son's appetite } \\
\text { is higher than his age. } \\
\text { rheme } 4\end{array}$ & $\begin{array}{l}\text { From the paragraph, we } \\
\text { can see that the paragraph } \\
\text { uses zig-zag pattern. It is } \\
\text { because the rheme in the } \\
\text { previous clause contains } \\
\text { an element be the theme } \\
\text { of the next clause. }\end{array}$ \\
\hline 2 & $\begin{array}{l}\text { Even though both parents really love their } \\
\text { son Babu Solong. But they can't help but } \\
\text { feel burdened by the habits of their son who } \\
\text { eat too much. Over time, because they } \\
\text { could no longer meet the food needs of their } \\
\text { very large child, Babu's parents searched for } \\
\text { ideas. Both Babu Solong's parents agreed to } \\
\text { eliminate their child. But without them } \\
\text { realizing it while discussing Babu Solong } \\
\text { accidentally overheard their conversation. }\end{array}$ & $\begin{array}{l}\text { Even though both parents } \\
\text { really love their son Babu } \\
\text { Solong. Theme } 1 \\
\text { Over time, because they } \\
\text { could no longer meet the } \\
\text { food needs of their very } \\
\text { large child.theme } 2 \\
\text { Both Babu Solong's par- } \\
\text { ents agreed to eliminate } \\
\text { their child. Theme } 3\end{array}$ & $\begin{array}{l}\text { But they can't help but feel } \\
\text { burdened by the habits } \\
\text { of their son who eat too } \\
\text { much. rheme } 1 \\
\text { Babu's parents searched } \\
\text { for ideas. Rheme } 2\end{array}$ & $\begin{array}{l}\text { From the paragraph, we } \\
\text { can see that the } \\
\text { paragraph uses a } \\
\text { hierarchical pattern,. It is } \\
\text { because each theme and } \\
\text { rheme introduces a } \\
\text { number of different } \\
\text { pieces of information, } \\
\text { then each is taken and the } \\
\text { next clause is made. }\end{array}$ \\
\hline
\end{tabular}




\begin{tabular}{|c|c|}
\hline Paragraph & Sentences \\
\hline 3 & $\begin{array}{l}\text { One day Ambe Babu Solong invited Babu } \\
\text { Solong to go find wood in the middle of the } \\
\text { forest. They left early in the morning to } \\
\text { reach the middle of the forest by midday. } \\
\text { Arriving at in the middle of the forest they } \\
\text { then choose the biggest and tallest tree to } \\
\text { be their firewood supply. So the two of them } \\
\text { started chopping the big wood. Every time } \\
\text { Ambe Babu Solong slashes wood with an } \\
\text { axe, Babu Solong digs Paris next to the tree. } \\
\text { And So until finally, the big tree fell on Babu } \\
\text { Solong. Thinking that his son had not been } \\
\text { hit by a tree, then Ambe Babu Solong went } \\
\text { home. But with his power and big body, } \\
\text { Babu Solong with his great strength moved } \\
\text { the tree. With a sad feeling, Babu Solong } \\
\text { then lifted the big tree up to his house. } \\
\text { When he arrives at his house, then he told } \\
\text { his parents that he knew they want to } \\
\text { eliminate him. But he understands his } \\
\text { parent's great difficulties so he decided to } \\
\text { leave his parents. }\end{array}$ \\
\hline
\end{tabular}
leave his parents.

Theme
One day Ambe Babu
Solong invited Babu So-
long/theme 1
They left early in the
morning/theme 2
Arriving in the middle of
the forest/theme 3
So the two of them/theme
4
Every time Ambe Babu So-
long slashes wood with an
ax/theme 5
And So/theme 6

Babu Solong went away to find a new place to live. On his way, he met a trader. He begged the trader so he can come with him. The trader agrees Babu Solong follows him. Then they continue their journey. In the middle of their way, a runaway slave also wants to join them. So they all three continue their journey. While they took a rest, an orphan young boy begged the trader that he let him join them. The trader agreed because they will all need to help the trader in the market. Because they are all hungry, they decided to stay near a pond. It was full of fish. The trader then asked Babu Solong and the two boys caught all the fish for their dinner. After that, they want to cook the fish but unfortunately, they didn't have a pot to steam the fish. Babu Solong offers help that he will go to the nearest village to borrow a clay pot. After walking for a while he arrives at one village.

Rheme Analysis

Thinking that his son had not been hit by a tree,/theme 7

But with his power and big body/theme 8 Babu Solong with his great strength moved the tree./rheme 8 With a sad feeling/theme 9

When he arrives at his house,/theme 10

But he understands his parent's great difficulties/theme 11

to go find wood in the mid-

dle of the forest./rheme 1

to reach the middle of the forest by midday/rheme 2 they then choose the biggest and tallest tree to be their firewood supply./rheme 3

started chopping the big wood./rheme 4

Babu Solong digs Paris next to the tree./rheme 5

until finally, the big tree fell on Babu Solong./rheme 6

then Ambe Babu Solong went home./rheme 7

Babu Solong then lifted the big tree up to his house./rheme 9

then he told his parents that he knew they want to eliminate him/rheme 10 so he decided to leave his parents. /rheme 11

Babu Solong went
away/theme 1 On his way/theme 2 $\mathrm{He}$ begged to the trader/theme 3 The trader agree/theme 4

Then they/theme 5 In the middle of their way/theme 7

The trader agreed/theme

Because they are all hungry, /theme 9

It was/theme10

The trader then asked Babu Solong/theme 11

After that, they want to cook the fish but unfortunately/theme 12

Babu Solong offer help/theme 13

to the find a new place to live./rheme 1 he met a trader/rheme 2

so he can come with him/rheme 3

Babu Solong to follow him./rheme 4

continue their journey./rheme 6

a runaway slave also wants to join them./rheme 7

because they will all need to help the trader in the market/rheme 8

pond/rheme 9 full with

they decided to stay near a fish./rheme 10

and the two boys caught all the fish for their dinner/rheme 11

they didn't have a pot to steam the fish/rheme 12

that he will go to the nearest village to borrow a clay pot/rheme 13

After walking for a he arrives at one vilwhile/theme 14 lage/rheme 14 .
From the paragraph, we can see that the paragraph uses a combination pattern,. It is because each theme and rheme that used in the paragraph were randomly and they scattered.
From the paragraph, we can see that the paragraph uses a hierarchical pattern, It is because each theme and rheme introduces a number of different pieces of information, then each is taken and the next clause is made. 


\begin{tabular}{|c|c|c|c|c|}
\hline Paragraph & Sentences & Theme & Rheme & Analysis \\
\hline 5 & $\begin{array}{l}\text { The village is really quiet. But Babu Solong } \\
\text { can see all things around him were bigger } \\
\text { than its size. Then he entered a place for } \\
\text { cook. There he opened the lid of the claypot } \\
\text { and he saw that it was full of human body. } \\
\text { Babu Solong then knew that he had entered } \\
\text { a giant village. All the giants eat human } \\
\text { being. Eventhough babu Solong was scared } \\
\text { but he knew that he had to do something. }\end{array}$ & $\begin{array}{l}\text { Then he/theme } 3 \\
\text { There he opened the lid of } \\
\text { the claypot/theme } 4 \text { and } \\
\text { he saw that it was full of } \\
\text { human body/rheme } 4 \\
\text { Babu Solong then knew } \\
\text { /theme } 5 \\
\text { All the giants/theme } 7 \text { eat } \\
\text { human being/rheme } 7 \\
\text { Eventhough babu Solong } \\
\text { was scared/theme } 8\end{array}$ & $\begin{array}{l}\text { is really quiet/rheme } 1 \\
\text { can see all things around } \\
\text { him was bigger than its } \\
\text { size./rheme } 2 \\
\text { entered a place for } \\
\text { cook/rheme } 3\end{array}$ & $\begin{array}{l}\text { From the paragraph, we } \\
\text { can see that the } \\
\text { paragraph uses a } \\
\text { hierarchical pattern, It is } \\
\text { because each theme and } \\
\text { rheme introduces a } \\
\text { number of different } \\
\text { pieces of information, } \\
\text { then each is taken and the } \\
\text { next clause is made. }\end{array}$ \\
\hline 6 & $\begin{array}{l}\text { He thinks a way to eliminate all the giants. } \\
\text { He took his axe and knock at a door. } \\
\text { Suddenly the giant's head appear, but } \\
\text { before the giant got out from his house, } \\
\text { Babu Solong chop off the giant's head. He } \\
\text { kept doing that until all giants were killed. } \\
\text { Then he went back to the trader and told his } \\
\text { story. The trader was very grateful because } \\
\text { of his braveness. When they went to the } \\
\text { giant's village, there they found many gold } \\
\text { and treasures. They took all the gold and } \\
\text { treasure for them. }\end{array}$ & $\begin{array}{l}\text { He kept doing that/theme } \\
4 \\
\text { The he went back to the } \\
\text { trader/theme } 5 \\
\text { The trader was very grate- } \\
\text { ful /theme } 6 \\
\text { When they went to the gi- } \\
\text { ant's village,/theme } 7 \\
\text { They took all the } \\
\text { gold/theme } 8\end{array}$ & $\begin{array}{l}\text { to eliminate all the gi- } \\
\text { ants/rheme } 1 \\
\text { and knock at a } \\
\text { door/rheme } 2 \\
\text { but before the giant got } \\
\text { out from his house, Babu } \\
\text { Solong chop off the giant's } \\
\text { head./rheme } 3 \\
\text { until all giants were } \\
\text { killed./rheme } 4 \\
\text { and told his story./rheme } \\
5 \\
\text { because of his brave- } \\
\text { ness./rheme } 6 \\
\text { there they found } \\
\text { many golds and trea- } \\
\text { sures/rheme } 7 \\
\text { and treasure for } \\
\text { them/rheme } 8\end{array}$ & $\begin{array}{l}\text { From the paragraph, we } \\
\text { can see that the } \\
\text { paragraph uses a } \\
\text { hierarchical pattern, It is } \\
\text { because each theme and } \\
\text { rheme introduces a } \\
\text { number of different } \\
\text { pieces of information, } \\
\text { then each is taken and the } \\
\text { next clause is made. }\end{array}$ \\
\hline 7 & $\begin{array}{l}\text { The trader asked babu Solong to be his } \\
\text { servants, but he reject it. He thankful to the } \\
\text { trader and wants to go home. He became a } \\
\text { rich man. Babu Solong makes his long } \\
\text { journey to come to his village to see his } \\
\text { parents. After he arrived, he told the } \\
\text { parents his story. His parents were feeling } \\
\text { very sorry to their son. They asked } \\
\text { forgiveness. Babu Solong and his parents } \\
\text { become a wealthy family and live happily } \\
\text { ever after. }\end{array}$ & $\begin{array}{l}\text { The trader asked babu } \\
\text { Solong to be his ser- } \\
\text { vants,/theme } 1 \\
\text { He thankful to the } \\
\text { trader ; He became a } \\
\text { rich man./theme } 2 \\
\text { Babu Solong make his long } \\
\text { journey/theme } 3 \\
\text { After he arrived/theme } 4 \\
\text { His parents were feeling } \\
\text { very sorry/theme } 5 \\
\text { They asked forgive- } \\
\text { ness./theme } 6 \\
\text { Babu Solong and his par- } \\
\text { ents become a wealthy } \\
\text { family and live happily } \\
\text { ever after./theme } 7\end{array}$ & $\begin{array}{l}\text { and wants to go } \\
\text { home./rheme } 2 \\
\text { to come to his village to } \\
\text { see his parents/rheme } 3 \\
\text { he told the parents his } \\
\text { story/rheme } 4 \\
\text { to their son./rheme } 5\end{array}$ & $\begin{array}{l}\text { From the paragraph, we } \\
\text { can see that the } \\
\text { paragraph uses a } \\
\text { hierarchical pattern, It is } \\
\text { because each theme and } \\
\text { rheme introduces a } \\
\text { number of different } \\
\text { pieces of information, } \\
\text { then each is taken and the } \\
\text { next clause is made. }\end{array}$ \\
\hline
\end{tabular}

\section{Socio-Cultural Aspects of Babu Solong Folktale}

Folktales are stories that give people a way of communicating with each other about each other- their fears, their hopes, their dreams, their fantasies, giving their explanations of why the world is the way it is [16]. It is in stories like these that a child learns who his parents are and who he will become. Folktales have been the cement of society. They not only expressed but codified and reinforced the way people thought, felt, believed and behaved [17]. There are four elements that made the folktale are closely related to the socio-cultural. Firstly, folklore is related to culture in the sense that it is, as previously mentioned, a mirror of culture. Folklore reflects culture because it relates to the 
way of life of the people who produce it: their ceremonies, their institutions, their crafts, and so on. It also expresses their beliefs, customs, attitudes and their way of thinking. Secondly, language and culture are related to each other in two respects: language is, like folklore, a mirror of culture and it is an integral part of the culture as well. Language as a mirror of culture represents an expression of both culture and the individuality of the speaker, who perceives the world [18]. Actually, language reflects the culture of the folk that speaks it and through language, one can learn much about the culture in which a language is set or used. Thirdly, culture and translation are linked because, as previously mentioned, translating involves the consideration of the source and target language cultures. Translation is now defined as a means of intercultural communication, a means to make up for cultural differences. When folktales were transferred or translated to the target language, generally the story will absorb the culture of how the story were told by the storyteller. Moreover, any translation produced should fit into the target culture of the target language. In the story of Babu Solong, the elements of socio-cultural can be found in some parts of the story. The sociological identity of the story was implicitly stated in the part of the story so as the cultural aspects. Some sociocultural aspect that found in the story like:

1. The description of the place as a place lies in highland of Mamasa.

2. The culture of the people who lived as a farmer were stated in the story. The way they lived and method of living were described in the story. Such as they used wood as a firing tool. They use axe and clay pot to cook.

3. As a villager we can conclude that Babu Solong parents were simple and rather old fashioned in the way they think.

4. Babu Solong was grown up as a simple, obedient son, kind person.

5. Generally, in Mamasa the

\section{Conclusion}

Folklore grows in the midst of society and the author is unknown or anonymous. Folklore provides an overview of culture, lifestyle, outlook on life, and the ideals of society. Folklore can be explored, but it is also important to examine the structure of the meaning or content of the story so that the content of folklore can be better understood and more useful. Folklore is something that is considered as wealth belonging to the people who are socially related to other people [19]. In folklore, it can be seen that there are various actions of language, use, to show the values in society. From the story of Babu Solong's original folktale from Mamasa West Sulawesi, we can generate some findings. As follows

1. The story of babu Solong contain several disourse elements that shown in each sentence of the story. Two of them are theme and rhemes.

2. There are four patterns of theme and rheme in the story. Namely: zig-zag pattern, re-iteration pattern, combination pattern and hierarchical pattern. But the pattern that is mostly used in the story is a hierarchical pattern.

3. From the story, we can also gain sociocultural aspect that lies inside the story. Which is the description of the villager's wisdom of life and their local cultures.

4. By identifying the discourse element of the story of Babu Solong, it is hoped that we can gain new information about the story. The socio-cultural aspect covers the society described in the story.

\section{References}

[1] L. R. Waugh, The Poetic Function in the Theory of Roman Jakobson, Poetics Today. Duke University Press, 1980

[2] D. Nunan, Introducing Discourse Analysis', UK: England. Penguin Group, 1993

[3] T. Bloor, and M. Bloor, The Functional Analysis of English: A Hallidayan Approach. London: Arnold, 2004

[4] D. Butt, R. Fahey, Feez, S. Spinks, and C. Yallop, Using Functional Grammar: an explorer's guide. Sydney: NCELTR, 2001

[5] G. Thompson, Introducing Functional Grammar. London: Edward Arnold, 2014

[6] S. Eggins, An introduction to functional linguistics. London: Continum Internasional Publishing Group,2004

[7] M. A. K. Halliday, An introduction to functional grammar: 2nd edition. London: Edward Arnold, 1994

[8] G. Brown and G. Yule, Discourse Analysis. Cambridge: Cambridge University Press, 1983

[9] H. Bussmann. (Ed.), Routledge dictionary of language and linguistics; translated and edited by Gregory Trauth and Kerstin Kazzazi. London: Routledge, 1998

[10] Faruk, Pengantar Sosiologi sastra dan Budaya. Pustaka Pelajar: Yogyakarta, 1999 
[11] N. Rurangwa, 'Translating Rwandan folktales into English: Aculture-analysis"Thesis Dissertation. Ph.D. Faculty of Humanities, School of Literature and Language (Translation and Interpreting Studies), 2005

[12] A. Asra, et al., " Representasi makna lagu bugis mappadendang melalui pendekatan hermeneutika," CLLT Journal, 2017

[13] Moleong, ' 'Metodologi Penelitian Kualitatif”, Edisi Revisi. Jawa Barat: PT. Remaja Rosdakarya, 2007

[14] T. Gunawan, et al., Figurative language used in Blackpink featuring Selena Gomez's song lyric "Ice Cream": A discourse analysis. Journal of Applied studies in language vol.5, p 1-9, 2001

[15] M. McCarthy. 'Discourse analysis for language teachers". Cambridge University Press, 1991.

[16] N. Rurangwa. 'Translating Rwandan folktales into English: A culture-analysis", Thesis Dissertation.PhD Faculty of Humanities, School of Literature and Language (Translation and Interpreting Studies), 2005

[17] M.H. Arbuthnot, 'Children and Books", $3^{\text {rd }}$ ed. Chicago: Scott, Foresman \& Company, 1964

[18] M.S. Hornby , Translation Studies: An Integrated Approach Amsterdam. Philadelphia: John Benjamins, 1988

[19] R. Gusnetti, S. Isnanda, et.al., "Struktur dan nilai-nilai pendidikan dalam cerita rakyat Kabupaten tanah datar Provinsi Sumatera Barat", JURNAL GRAMATIKA Jurnal Penelitian Bahasa dan Sastra Indonesia V1.i2, (183-192), 2015 